\title{
HEPATOPROTECTIVE EFFECT OF 50\% ETHANOL EXTRACT OF SEAGRASS RHIZOME (CYMODOCEA ROTUNDATA) AGAINST LIVER TISSUES IN PARACETAMOL-INDUCED RATS
}

\author{
RENITA DEWI, RAESHA DWINA MALIKA, ADE MARA MEILANI, FADLINA CHANY SAPUTRI*
}

Department of Pharmacology, Faculty of Pharmacy, Universitas Indonesia, Depok, 16424, Indonesia. Email: fadlina.chany@farmasi.ui.ac.id

Received: 12 April 2018, Revised: 29 September 2018, Accepted: 29 November 2018

ABSTRACT

Objective: This study aimed to determine the hepatoprotective effect of 50\% ethanol extract of seagrass rhizome in terms of serum glutamic oxaloacetic transaminase (SGOT) and serum glutamic pyruvic transaminase (SGPT) activities in paracetamol-induced rat plasma.

\begin{abstract}
Methods: This study included 28 male, white rats randomly divided into seven groups. Groups I and II represented the normal control and control groups, respectively, administered with $280 \mathrm{mg} / \mathrm{kg}$ BW of rhizome extract. Group III represented the negative control group induced by a suspension of paracetamol (2g/kg BW). Group IV represented a positive control group administered with Hepa- ${ }^{\circledR}$ at a dosage of $150 \mathrm{mg} / \mathrm{kg}$ BW. Groups V, VI, and VII were administered with seagrass rhizome extract at doses of 140,280, and $560 \mathrm{mg} / \mathrm{kg}$ BW, respectively, before paracetamol induction. The test material was orally administered for 17 days. On days $12-17$, the rats were induced with paracetamol through the same route. On day 18 , blood sampling was performed followed by SGOT and SGPT plasma measurements.
\end{abstract}

Results: Our results revealed that seagrass rhizome extracts could significantly decrease SGPT and SGOT levels in paracetamol-induced rats (p<0.05) compared with those in the negative control group.

Conclusion: Thus, seagrass rhizome extracts possess the potential for development as a hepatoprotective agent.

Keywords: Seagrass rhizome, Hepatoprotective, Paracetamol, Serum glutamic oxaloacetic transaminase, Serum glutamic pyruvic transaminase.

(C) 2018 The Authors. Published by Innovare Academic Sciences Pvt Ltd. This is an open access article under the CC BY license (http://creativecommons. org/licenses/by/4. 0/) DOI: http://dx.doi.org/10.22159/ijap.2018.v10s1.53

\section{INTRODUCTION}

Liver is a vital organ for survival, and it contributes to almost every metabolic function of the body [1]. In addition to playing an important role in the metabolism of carbohydrates, proteins, and fats, the liver also plays a role in the storage of vitamins, iron, and copper as well as in the detoxification of a large number of endogenous and exogenous substances [1]. The liver is involved in the synthesis, storage, and metabolism of several endogenous compounds and the clearance of exogenous compounds, including drugs and toxins from the body [2]. Liver damage can include fatty liver, necrosis, cholestasis, hepatitis, and liver cirrhosis [1]. Damage to the liver can be overcome by preventive (hepatoprotective) and curative (antihepatotoxic) efforts [3].

Based on these backgrounds, the liver needs to be maintained to function properly. Conventional drug therapy for various liver damage diseases, such as non-alcoholic fatty liver disease and viral hepatitis, has limited efficacy and potentially adverse effects. Treatment using extracts derived from natural resources, such as plants, is considered to be the best method to maintain liver functions in the long-term without significantly inducing toxic effects [4].

Indonesia is a country with a vast maritime territory, and hence, it is called a maritime country. Indonesia's marine biota has great potential for exploration, particularly in the field of health. One of the marine biotas that can be used for health is the seagrass rhizome (Cymodocea rotundata). Seagrass rhizome is a dominant species of seagrass that is easily found in almost all Indonesian waters. Seagrass rhizome possesses high productivity in Indonesia but has not been matched by optimal utilization [5]. The utilization of seagrass rhizomes as a hepatoprotective agent is one way to improve optimization of seagrass utilization in the field of health.

Based on previous studies, seagrass rhizome is believed to possess high antioxidant content, which is indicated by a good $\mathrm{IC}_{50}$ value, as analyzed by the 1, 1-diphenyl- $\beta$-picrylhydrazyl-scavenging activity $(8 \pm 0.745)$ and ferric-reducing antioxidant power method $(1.39 \pm 0.32)$. The antioxidant content is an important parameter that determines the hepatoprotective activity. Considering the high antioxidant content in seagrass rhizomes, it is necessary to test the hepatoprotective effect of seagrass rhizome on the liver. Research on the hepatoprotective effect of seagrass rhizomes was conducted to determine the ability of seagrass rhizomes to prevent or protect the liver from damage. Parameters observed included aspartate aminotransferase and alanine aminotransferase (serum glutamic oxaloacetic transaminase [SGOT] and serum glutamic pyruvic transaminase [SGPT], respectively) activities in the blood plasma. Liver cells containing various enzymes, such as SGOT and SGPT, are important for the diagnosis of liver damage because the enzyme is passed into the blood vessels. Estimation of enzyme activity may thus indicate the presence of liver disease [6].

\section{METHODS}

\section{Seagrass rhizome extracts}

Seagrass rhizomes were obtained from the Thousand Islands, Jakarta. The voucher specimen was deposited at Center for Plant Conservation Botanic Gardens. Dry powdered seagrass rhizome $(50 \mathrm{~kg})$ was macerated with $50 \mathrm{~L}$ of $50 \%$ ethanol for $5 \times 24 \mathrm{~h}$ with continuous shaking. The maceration was repeatedly performed until the collected filtrate was colorless. The final filtered product was then evaporated with the solvent using a rotary evaporator with a vacuum pump, after which the obtained extract was concentrated by placing on a water bath at approximately $50^{\circ} \mathrm{C}$ to obtain a viscous extract. Since the marine natural material has a high salt content, the viscous extract obtained was centrifuged at $6000 \mathrm{rpm}$ for $15 \mathrm{~min}$ [7].

Identification of flavonoids in seagrass rhizome extracts A total of $\pm 0.2 \mathrm{~g}$ of the obtained extract was added to $50 \mathrm{~mL}$ of hot water and then boiled for $5 \mathrm{~min}$, followed by filtration to obtain a 
filtrate, which was used as the experimental solution. To $5 \mathrm{~mL}$ of the experimental solution, $\mathrm{mg}$ powder and $1 \mathrm{~mL}$ of concentrated $\mathrm{HCl}$ were added. Next, amyl alcohol was added, and the mixture was vigorously shaken to allow separation. The development of red, yellow, or orange color in the amyl alcohol solution indicated the presence of flavonoid group compounds [8].

\section{Experimental animals}

This study was approved by the Ethics Committee of Faculty of Medicine, Universitas Indonesia (No. 154/UN2.F1/ETIK/2018). Male, white Sprague-Dawley rats (Rattus norvegicus) were used as the experimental animals. The animals were approximately 2 months old with a body weight of 150-200 g. The experimental animals were acclimatized for 1 week and then observed daily by monitoring weight gain and health conditions.

\section{Experimental animal treatment}

The experimental animals were randomly divided into seven groups. The test animals were treated for 17 days; on day 12 until day 17, the animals were induced with paracetamol and their blood was collected on day 18. Table 1 shows the experimental scheme that was planned. Note that the colored block means there is an experiment given to the mentioned group.

\section{Determination of SGOT and SGPT plasma levels}

SGOT and SGPT blood activities were determined using the kinetic principle established by the International Federation of Chemical Chemistry using a UV-Vis spectrophotometer. Plasma $(50 \mu \mathrm{L})$ of the experimental animals was obtained on day 18 and mixed with $1000 \mu \mathrm{L}$ of SGOT and SGPT reagents and then vortexed and incubated at $37^{\circ} \mathrm{C}$ for $1 \mathrm{~min}$ followed by measurement of absorbance using a spectrophotometer at $340 \mathrm{~nm}$ wavelength for SGOT and SGPT activities. The sample absorbance measurements were performed for 3 min with recorded uptake at the $1^{\text {st }}, 2^{\text {nd }}$, and $3^{\text {rd }} \mathrm{min}$. Results of SGOT and SGPT activities are expressed in units/liter (U/L). SGOT and SGPT activities were calculated using the following formula; activity SGOT/SGPT (U/L) $37^{\circ} \mathrm{C}=\Delta \mathrm{A} / \min \times 1746$ (conversion factor).

\section{Data analysis}

Data obtained were statistically processed using SPSS 24.0. The first analysis was the normality test (Shapiro-Wilk Test) and homogeneity test (Levene test). The analysis was then continued by one-way analysis of variance to examine the relationship among all treatment groups as well as to determine whether data were normally distributed and homogeneous. Then, the analysis continued with the smallest differential differences test Boston naming test to evaluate differences among the treatment groups. The Kruskal-Wallis test was performed for evaluating the relationship among all treatment groups and for testing whether data were normally distributed and homogeneous. Then, the analysis was continued with the Mann-Whitney U-test to examine differences among the treatment groups. Tests were performed to determine significant differences between two unrelated treatment groups by independent t-test and to examine whether data were normally distributed and homogeneous.

\section{RESULTS}

Identification of flavonoids in seagrass rhizome extract

The flavonoids test on seagrass rhizome extract revealed positive results, which were indicated by the formation of yellow-orange color in the amyl alcohol layer.

\section{Measurement results of SGOT and SGPT}

Fig. 1 shows Seagrass rhizome extracts effect profile on SGPT and SGPT levels. As shown in Table 2, Group I showed significantly lower SGOT levels than Group III $(\mathrm{p}<0.05)$, which indicates that the mean SGOT level was $73.05 \mathrm{U} / \mathrm{L}$ in Group I and 153.44 U/L in Group III. The SGOT level in Group I in the normal range according to Girindra (1989), that is, 45.7-80.8 U/L, whereas that of Group III was above the normal range. Group III showed the significantly highest SGOT level compared with all other groups $(\mathrm{p}<0.05)$. Group IV showed significantly lower SGOT levels than Group III $(\mathrm{p}<0.05)$, but higher and insignificant level than Groups I, II, and VI. Group II showed the lowest average SGOT levels among all other groups. The group of dose variations showing an average SGOT level closest to that of Group I (normal) was Group VI. In addition, Group VI tended to show lower SGOT levels than the group administered with the Hepa-Q drug.

As seen in Table 2, Group I showed significantly lower SGPT level $(29.39 \mathrm{U} / \mathrm{L})$ than Group III $(111.89 \mathrm{U} / \mathrm{L})(\mathrm{p}<0.05)$. SGPT levels in Group I were in the normal range, according to Girindra (1989), that is, it ranged from 17 to $30.2 \mathrm{U} / \mathrm{L}$. Group III had the highest levels of SGPT significantly compare to all other groups $(p<0.05)$, with the average SGPT level being above the normal levels. Group IV showed significantly lower SGPT levels than Group III, but significantly higher levels than Group I $(\mathrm{p}<0.05)$. Group II showed the lowest average SGPT

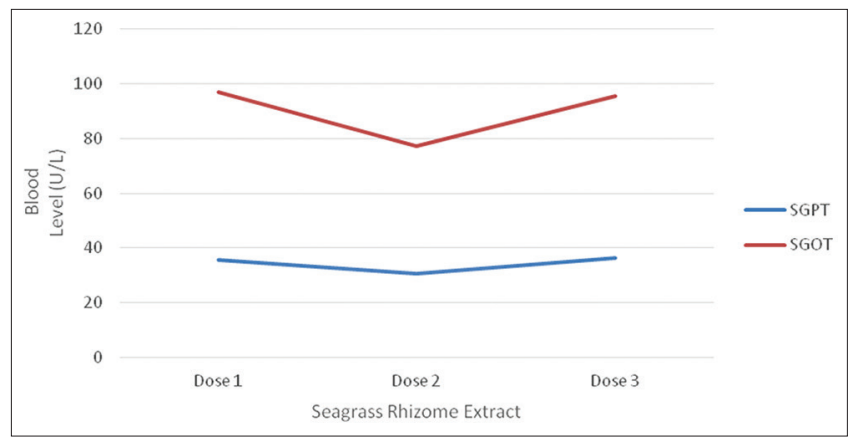

Fig. 1: Seagrass rhizome extracts effect profile on serum glutamic pyruvic transaminase and serum glutamic pyruvic transaminase levels

Table 1: Experimental scheme

\begin{tabular}{|c|c|c|c|c|c|c|c|}
\hline \multirow[t]{2}{*}{ Treatment } & \multicolumn{7}{|c|}{ Group } \\
\hline & I & II & III & IV & $\mathbf{V}$ & VI & VI \\
\hline \multicolumn{8}{|l|}{ Treatment (day 1-17) } \\
\hline \multicolumn{8}{|l|}{ CMC $0.5 \%$} \\
\hline \multicolumn{8}{|l|}{ Hepa-Q ${ }^{\circledR}(150$ mg/kg BW $)$} \\
\hline \multicolumn{8}{|l|}{ Seagrass extract dose $1(140 \mathrm{mg} / \mathrm{kg} \mathrm{BW})$} \\
\hline \multicolumn{8}{|l|}{ Seagrass extract dose 2 (280 mg/kg BW) } \\
\hline \multicolumn{8}{|l|}{ Seagrass extract dose $3(560 \mathrm{mg} / \mathrm{kg} \mathrm{BW})$} \\
\hline \multicolumn{8}{|l|}{ Hepatotoxic induction (day 12-17) (paracetamol 2 g/kg BW) } \\
\hline Blood collection (day 18) & & & & & & & \\
\hline
\end{tabular}

Description: Group I: Normal group, Group II: Control group administered the extract (280 mg/kg BW, orally), Group III: Negative control group, Group IV: Positive control group (Hepa- ${ }^{\circledR}$ at $150 \mathrm{mg} / \mathrm{kg}$ BW, orally), Group V: Test group administered with the seagrass rhizome extract dose 1 (140 mg/kg BW, orally), Group VI: Test group administered with the seagrass rhizome extract dose $2(280 \mathrm{mg} / \mathrm{kg} \mathrm{BW}$, orally), and Group VII: Test group administered with the seagrass rhizome extract dose 3 (560 mg/kg BW, orally) 
Table 2: Examined SGOT and SGPT levels

\begin{tabular}{|c|c|c|c|c|c|c|c|}
\hline \multirow[t]{2}{*}{ Treatment } & \multicolumn{7}{|l|}{ Mean \pm SD } \\
\hline & I & II & III & IV & V & VI & VII \\
\hline SGOT levels (U/L) & $73.05^{*} \pm 9.42$ & $70.09 * \pm 3.79$ & $153.44^{\#} \pm 59.06$ & $86.57 * \pm 19.42$ & $97.01 * \pm 10.56$ & $77.43^{*} \pm 11.59$ & $95.72 * \pm 19.73$ \\
\hline
\end{tabular}

Description: Group I: Normal group, Group II: Control group administered the extract ( $280 \mathrm{mg} / \mathrm{kg}$ BW, orally), Group III: Negative control group, Group IV: Positive control group (Hepa- ${ }^{\circledR}$ at $150 \mathrm{mg} / \mathrm{kgBW}$, orally), Group V: Test group administered with the seagrass rhizome extract dose 1 (140 mg/kg BW, orally), Group VI: Test group administered with the seagrass rhizome extract dose $2(280 \mathrm{mg} / \mathrm{kg}$ BW, orally), and Group VII: Test group administered with the seagrass rhizome extract dose 3 (560 mg/kg BW, orally). \#Significantly differed from the normal control group ( $\mathrm{p}<0.05)$; *Significantly differed from the negative control group ( $<<0.05$ ).

SGOT: Serum glutamic oxaloacetic transaminase, SGPT: Serum glutamic pyruvic transaminase, SD: Standard deviation

levels among all other groups. The group of dose variations with an average SGOT level closest to that of the normal group was Group VI. In addition, Group VI tended to show lower larger SGOT levels than the group administered with the Hepa-Q drug.

\section{DISCUSSION}

Group I comprised rats under normal conditions, that is, with SGOT and SGPT levels in the normal range probably because this group was not induced by paracetamol and, therefore, paracetamol-induced liver damage did not occur. Group III was induced with paracetamol without administration of medication or seagrass rhizome extract, and it showed the highest SGOT and SGPT levels at a level significantly higher than that of all other groups $(\mathrm{p}<0.05)$. This result can be explained by Goodman and Gilman's [9] statement that when paracetamol is consumed in high doses, it is metabolized through the cytochrome $\mathrm{P} 450$, which spontaneously converts paracetamol N-hydroxylated to form a hepatotoxic $\mathrm{N}$-acetyl-p-benzoquinone imine metabolite that has the potential to cause heart damage. SGPT and SGOT levels in the blood plasma increase in case of damage to liver cells. SGPT and SGOT enzymes are transaminase-class enzymes that can be found in the liver and serve as sensitive indicators of liver cell damage [10].

Group IV rats could significantly lower their plasma SGOT and SGPT levels as compared with Group III rats, which suggest that Hepa-Q drug administered in Group IV significantly lowered SGOT levels in paracetamol-induced mice. The group administered with seagrass rhizome extracts showed decreased blood plasma SGOT and SGPT levels because its flavonoid compounds had potentially high antioxidant activity. Seagrass rhizome is known to possess the best antioxidant activity compared with other seagrass species because it has high flavonoid levels. Antioxidant content is an important parameter that determines the hepatoprotective activity [11].

\section{CONCLUSION}

Based on the research, it can be concluded that $50 \%$ ethanol extract of seagrass rhizome can significantly decrease SGPT and SGOT levels in paracetamol-induced rats $(\mathrm{p}<0.05)$, with the effective dose of
$280 \mathrm{mg} / \mathrm{kg}$ BW. Our results suggest that this extract can be developed into an hepatoprotective agent.

\section{ACKNOWLEDGMENT}

This research was supported by Faculty of Pharmacy, Universitas Indonesia, and funded by the Ministry of Research, Technology, and Higher Education, Republic of Indonesia.

\section{CONFLICTS OF INTEREST}

None declared.

\section{REFERENCES}

1. Price SA, Wilson LM. Pathophysiology: Clinical Concepts of Disease Processes. Jakarta: EGC Medical Book Publishers; 2005.

2. Kenward R, Chik KT. Clinical pharmacy. In: Aslam M, Tan CK, Prayitno A, editors. Toward Rational Treatment and Acknowledgement of Patient Choice. Jakarta: PT Gramedia; 2003.

3. Linawati Y, Apriyanto A, Susanti E, Wijayanti I, Donatus A. Hepatoprotective effect of herbal decoction of putri malu (Mimmosa pigra L.) in rats induced paracetamol. J Farmasi Indones 2007;2007:217.

4. Umer S, Asres K, Veeresham C. Hepatoprotective activities of two Ethiopian. Pharm Biol 2010;48:461-8.

5. Montano MN, Bonifacio RS, Rumbaoa RG. Proximate analysis of the flour and starch from Enhalus acoroides (L.f) royle seeds. J Aqu Botany 1999;65:321-5.

6. Sari W. Care Your Self: Hepatitis. Jakarta: Penebar Plus; 2008.

7. Elya I, Yasman T. Test Activity Inhibition of Thyrosinase Five Seagrass Extract Collected from Kepulauan Seribu Jakarta. Depok: Faculty of Pharmacy Universitas Indonesia; 2012.

8. Republic of Indonesia Ministry of Health. Indonesian Materia Medika. Vol. 4. Jakarta: Ministry of Health of the Republic of Indonesia; 1995. p. 119-23.

9. Goodman LS, Gilman A. Goodman, Gilman's The Pharmalogical Basic of Therapeutics. $6^{\text {th }}$ ed. New York: Mac Milan Publishing Co Inc.; 1980.

10. Lawrence AK, Amadeon JP. Clinical Chemistry: Theory, Analysis, Correlation. $3^{\text {rd }}$ ed. Philadelphia, PA: Mosby Year Book Inc.; 1996.

11. Jeyapragash D, Subhashini P, Raja S, Abirami K, Thangaradjou T. Evaluation of In-Vitro Antioxidant Activity of Seagrasses: Signals for Potential Alternate Source. India: Faculty of Marine Sciences, Tamil Nadu: Annamalai University; 2016. 